\title{
Problems of the Azerbaijani Economy Diversification in Modern Conditions
}

\begin{abstract}
Shafa Aliyev ${ }^{1 *}$
${ }^{1}$ Sumgait State University, Azerbaijan

"Email:shafaaliyev@gmail.com

ABSTRACT

The article deals with the problems of diversification of the Azerbaijani economy in current conditions. Azerbaijan has formed a model of economic development considering the effective use of oil resources, which became the engine of the country's economy after the restoration of its independence connected with the former USSR collapse. The essence of the model of economic development of Azerbaijan and its essential features are revealed. Emphasis is placed on minimising the country's economy's dependence on the oil factor through intensive development and improving the efficiency of non-oil sectors of the economy. Priority directions of development of non-oil industries are considered, and their potential is analysed. The dynamics of GDP in the oil and non-oil sectors of the Azerbaijani economy is given. The share of the oil and non-oil sectors in the GDP of the country's economy is estimated. The industry structure by type of economic activity and some indicators of the non-oil sector of Azerbaijan are presented. The structure of the output of the non-oil sector of the country is given. The dynamics of attracting foreign investment in specific sectors of the Azerbaijani economy is reflected. The need to accelerate the development of specific non-oil sectors of the economy, characterised by high potential and competitiveness, is noted. Especially recommended is the expansion of activities in the field of heavy engineering, chemical and petrochemical, and the metallurgical industry of the non-oil sector of the industry. The importance of strengthening modernisation and developing targeted programs for equipping non-oil sectors of the country's economy with high technologies ensures its effectiveness is substantiated. Several recommendations and proposals on the problems of diversification of the Azerbaijani economy soon are given.
\end{abstract}

Keywords: Azerbaijan, Diversification, Problems of economic diversification, Structure of the Azerbaijani economy, Non-oil sector of the economy, Competitiveness of the economy, Prospects for diversification of the economy of Azerbaijan.

\section{INTRODUCTION}

Azerbaijani economy has been in an intensive phase of development in recent years. However, due to the negative consequences of the COVID-19 pandemic and the fall in oil prices on world markets, which are the primary source of foreign exchange income of the country, entirely new approaches and mechanisms are required to diversify the structure of the country's economy. First of all, the strategic objectives provide for the maximum reduction of the national economy's dependence on the oil factor and, thereby, ensure the intensification of the Azerbaijani economy's non-oil sector development. In late 2016, the year after the double devaluation of the national currency - manat, the government has taken measures to diversify the country economy, identified 11 areas of comprehensive development structure of the economy with the implementation of strategic roadmaps for promising sectors of the economy with efficient use of available resources in the country. So, by the President Decree of December 6, 2016, a document was adopted and approved, called "Strategic Road maps for the national economy and the main sectors of the economy" [1].

It should be emphasised that Azerbaijan has sufficient natural and economic resources to diversify the national economy. Also, by expanding oil and gas processing, it is possible to increase the volume of non-oil products 
significantly. In the country, competitive industries such as chemistry and petrochemistry, metallurgy, textile and food industries, agro-industrial complex, etc. were considered traditional. Thus, Azerbaijan is creating a modern and high-tech production infrastructure to develop the industries mentioned above, creating technoparks, industrial parks, high-tech parks, industrial districts, agro-industrial parks and creating the first free economic zone. The state invests a significant amount in strengthening the material and technical base and infrastructure capacity of the non-oil sectors of the country's economy. For example, in Sumgait, more than 23 residents are registered in the chemical industrial park, who have made long-term investments worth $\$ 3.2$ billion to create and develop competitive industrial enterprises of the processing cycle [2]. It produces competitive and export-oriented products, including polypropylene, linear polyethene, nitrogen fertilisers, various plastic products, electromechanical equipment, electrical cables, solar panels, glass, electronic products, etc. The production and export potential increases every year. In general, a severe ground is being formed in Azerbaijan to transition to innovative development of the country's economy by creating more competitive industrial enterprises in the non-oil sectors. The state's economic policy is also being strengthened to maintain sustainable economic growth by increasing the oil sector in the world's unstable economic situation and new challenges [3]. Integrative processes and interaction between research organisations, universities and non-oil industry entities are being activated to intensify, develop and apply innovations, innovative functions that can create more productive sources of the added value of a non-oil nature [4]. Innovatisation of non-oil sectors of the country's economy will make it possible to produce more knowledge-intensive and high-tech competitive products and form national brands for active access to world markets. In general, Azerbaijan considers economic growth and diversification of the national economy based on innovation as a tool for ensuring sustainable growth in the twenty-first century [5]. The fact is that ensuring the acceleration of innovation processes in various areas of the non-oil sector creates a more favourable and attractive innovation and investment environment for the activation of entrepreneurial activity and will cause a severe interest for business process participants. Such a strategic goal as sustainable production growth in the non-oil sector requires dynamism in business activities, active involvement of high technologies and development of intellectual resources [6].

The critical role of diversification and ensuring the efficiency of the non-oil sector of the Azerbaijani economy should be provided by a balanced state policy on regulating and improving economic processes and the country's economic development model, which will have to solve a serious diversification of the structure of the national economy in the coming years. Group of researchers O. Brendan, H. Terence, H. David, L. Patrick emphasise that: "The state can effectively influence the activation of existing resources for the expansion of business activities through the use of various support mechanisms, including financial preferences" [7]. Moreover, with the help of targeted programs and sound strategies, the state can implement comprehensive measures to deepen economic reforms in the country and increase the efficiency of cooperation "state - business sector - business environment". Research scientists $\mathrm{T}$. Gerard, F. Darragh and Mc. Stephen note that "The development of promising sectors of the country's economy through active cooperation of business entities and government agencies will create a stronger foundation for the national economy and ensure its immunity to counteract external factors, including global impacts" [8]. In other words, the state must repeatedly weigh the pros and cons that can contribute to the intensification of the development of the country's economy's main sectors with the elimination of existing severe problems and shortcomings that slow down the pace of economic development [9]. Based on the assumptions above and factors, it may be noted that in the coming years, Azerbaijan needs to improve its structure to decrease its dependence on oil and gas factors and, thus, require significant development of promising nonoil sectors of the national economy.

\section{RESEARCH METHODOLOGY}

Note that objective identification and evaluation of existing problems of diversification of Azerbaijani economy will require an in-depth analysis of the current state of the structure of the economy, identifying vulnerabilities in it, and the definition of strategic objectives for the country's economy in a new direction based on new technologies based on the requirements of modern realities, challenges. For this purpose, analysis and synthesis methods were used, but the emphasis is mostly on the author's approach to the considered problems. Will determine the significant directions of diversification of the economy through the effective use of the non-oil sectors, ensure they reach potential, expand refining capacities, and create a network of competitive high-tech enterprises in the short term.

\section{STUDY RESULTS}

After the collapse of the former Soviet Union, Azerbaijan needed to form an independent economic policy and effectively model its economic development as a sovereign state. Thus, on September 20, 1994, the "Contract of the Century" was signed, which ensured the oil strategy's successful implementation. The country has implemented deep economic reforms and created a favourable investment environment. It is no coincidence that about $\$ 300$ billion was attracted to the country's economy during the restoration of independence. As 
noted, modern industrial production facilities based on high technologies have been created in recent years [10]. A balanced state policy and approaches to expanding the country's economy's structure make it possible to increase the economic development model's sustainability and, thus, ensure its effective renewal. New directions of non-oil sectors, such as tourism, knowledge economy, digitalisation, expansion of information and communication technologies, can improve the structure of the country's economy [11]. The creation of high-tech spheres of non-oil sectors of the country's economy will significantly increase the competitiveness of the national economy and at the same time, increase its manoeuvrability. In other words, the country's economic components and mechanisms are becoming more resilient and competitive [12].

It should be noted that Azerbaijan has become an initiator and financial donor of significant oil and gas and transport projects not only in the region but also beyond its borders. A major project has been implemented to construct oil and gas pipelines, the ultimate goal of delivering energy resources to more expanded and financial-intensive markets of the world, primarily to the European market. Located at West-East's international crossroads, on the Silk Road, Azerbaijan has built an international railway route on the Silk Road together with Turkey and Georgia. In general, the country has a vital infrastructure for developing non-oil sectors of the economy, multifunctional logistics hubs have been created, and work is being intensively carried out to create a free economic zone based on the Alat International Seaport in the Caspian Sea. Through this port, the flow of cargo traffic increases every year and, above all, the potential for export and import of non-oil products increases.

To assess the current situation more objectively, the potential and reserves for solving the problems of diversification of the Azerbaijani economy in the context of new requirements and challenges, we present a brief analysis of several economic indicators related to the non-oil sector. figure 1 shows the volume of GDP in the oil and non-oil sector of the Azerbaijani economy, 20102019 , where it is could be observed that over the past 2 years, the share of the oil and gas sector has been declining and, conversely, the growth of the non-oil sector in the total GDP of the country has been noted.

To identify the most critical factors affecting the level of GDP (Y) of Azerbaijan, a regression and correlation analysis of indicators was carried out using mathematical and statistical methods (table 1 and table 2). The following variables were selected as dependent variables: GDP of the oil sector (X1), GDP of the non-oil sector (X2) and net taxes on products and imports (X3).

The result of the computer calculation is the following model:

$$
\begin{gathered}
Y=-0.021097844 \\
+1.001832931 X_{1}+1.002136219 X_{2}+0.977641639 X_{3} .
\end{gathered}
$$

The total correlation coefficient is $\mathrm{R}=0.999$; the standard error is 0.01304428 . According to Fischer's criterion, $\mathrm{F}$ (ext.) $=2585080.017$; where 95 - \% - F (crit.) $=1.75$. Simultaneously, according to the Student's $\mathrm{t}$ criterion, which characterises the formula's individual parameters, the final indicators are higher than the basic ones. Therefore, equality can be considered adequate.

Figure 2 compares the share of the oil and non-oil sectors in the Azerbaijani economy's GDP in 2010 and 2019. Thus, if in 2010 the share of the oil and gas sector in GDP amounted to $48 \%$, then in 2019 it was recorded at $36.8 \%$, and, conversely, during this period the share of the non-oil sector increased and, accordingly, these indicators were: $45.2 \%$ and $54.5 \%$.

Figure 3 shows the industry structure by type of economic activity in Azerbaijan for 2005-2019 and shows that a notable jump in a particular area has not been noticed. Thus, if in 2005 the share of the processing industry in the industrial structure was $25.5 \%$ and the extractive industry $-67.4 \%$, then similar indicators did

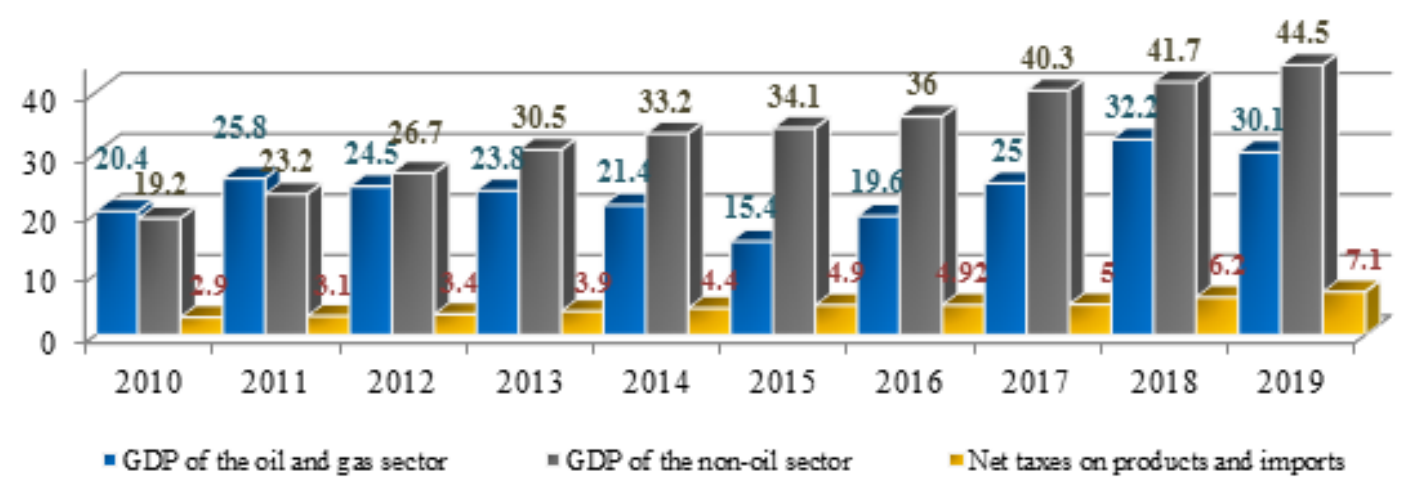

Figure 1 GDP in the oil and non-oil sector of the Azerbaijani economy, 2010-2019, billion manat (prepared based on materials of the State Statistical Committee of the Republic of Azerbaijan SSCRA - https://www.stat.gov.az/). 
Table 1. Regression and correlation analysis of GDP indicators of the oil sector, GDP of the non-oil sector and net taxes on products and imports of Azerbaijan

\begin{tabular}{|l|l|l|l|l|l|l|l|}
\hline Coefficients & Standard Error & t-statistics & P-Value & Lower 95\% & \multicolumn{1}{|c|}{ Top 95\% } & Lower 95.0\% & Top 95.0\% \\
\hline-0.021097844 & 0.028913929 & -0.729677507 & 0.493078166 & -0.09184768 & 0.049651993 & -0.09184768 & 0.049651993 \\
\hline 1.001832931 & 0.001111346 & 901.4591471 & $1.25782 \mathrm{E}-16$ & 0.999113565 & 1.004552296 & 0.999113565 & 1.004552296 \\
\hline 1.002136219 & 0.002833439 & 353.6819576 & $3.44803 \mathrm{E}-14$ & 0.995203044 & 1.009069394 & 0.995203044 & 1.009069394 \\
\hline 0.977641639 & 0.021773326 & 44.90088547 & $8.17309 \mathrm{E}-09$ & 0.924364229 & 1.03091905 & 0.924364229 & 1.03091905 \\
\hline
\end{tabular}

not change significantly in 2015 and 2019, respectively: $29.9 \%$ and $61.1 \% ; 25.1 \%$ and $69.9 \%$.

\section{0}

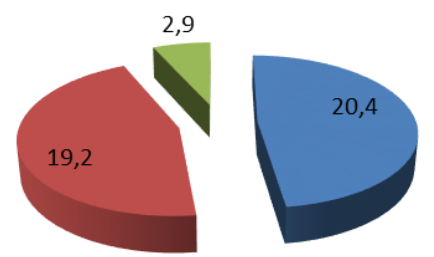

2019

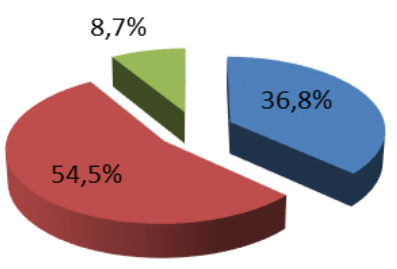

Figure 2 Share of the oil and gas and non-oil sectors in the GDP of the Azerbaijani economy in 2010 and 2019, $\%$ (prepared based on the materials of SSCRA https://www.stat.gov.az/).

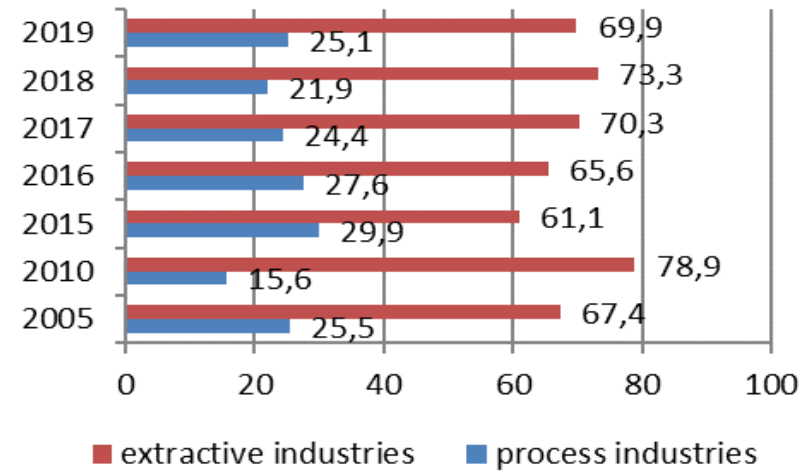

Figure 3 Structure of industry by type of economic activity in Azerbaijan for 2005-2019, \% of the total (prepared based on materials of SSCRA https://www.stat.gov.az/).

This situation in the industry structure leads to the implementation of serious measures to accelerate the development of the non-oil industry's promising areas.

The added value in the oil sectolele $r$ of Azerbaijan increased by $33.7 \%$ in $2015-2019$. However, during this period, the share of the oil sector's added value in the country's total GDP showed instability, thereby increasing the non-oil industry's share in the added value in the non-oil sector from $8.2 \%$ to $12.5 \%$.

Table 2. Regression and correlation analysis of indicators of the Azerbaijan non-oil sector

\begin{tabular}{|c|c|c|}
\hline Predicted $Y$ & Balances & Standard balances \\
\hline 42.4924701 & 0.007529898 & 0.706992153 \\
\hline 52.10644113 & -0.006441132 & -0.604766514 \\
\hline 54.70259174 & -0.002591744 & -0.243342326 \\
\hline 58.20048298 & -0.00048298 & -0.045347667 \\
\hline 58.99067256 & 0.009327443 & 0.875766068 \\
\hline 54.37041839 & -0.020418389 & -1.917109805 \\
\hline 60.38441135 & 0.01558865 & 1.463639131 \\
\hline 70.29902325 & 0.000976754 & 0.09170873 \\
\hline 79.11073938 & -0.010739382 & -1.008334951 \\
\hline 80.69274912 & 0.007250884 & 0.680795181 \\
\hline
\end{tabular}


Table 3. Some indicators of Azerbaijan's non-oil sector for 2015-2019

\begin{tabular}{|l|c|c|c|c|}
\hline \multicolumn{1}{|c|}{ Indicators } & 2015 & 2017 & 2018 & 2019 \\
\hline $\begin{array}{l}\text { Added value in the non-oil sector, billion } \\
\text { manat }\end{array}$ & 37.7 & 44.1 & 46.7 & 50.4 \\
\hline $\begin{array}{l}\text { Share of added value of the non-oil sector in } \\
\text { total GDP, \% }\end{array}$ & 69.3 & 62.8 & 58.5 & 61.7 \\
\hline $\begin{array}{l}\text { Share of non-oil industry in added value in the } \\
\text { non-oil sector, \% }\end{array}$ & 8.2 & 7.0 & 7.1 & 12.5 \\
\hline $\begin{array}{l}\text { The volume of production in the non-oil } \\
\text { industry, million manats }\end{array}$ & 7660.3 & 9484.8 & 10047.9 & 11321.7 \\
\hline
\end{tabular}

Source: Ministry of Economy of Azerbaijan. Retrieved from: https://www.economy.gov.az

In table 3, some indicators of Azerbaijan's non-oil sector for 2015-2019 are analysed.

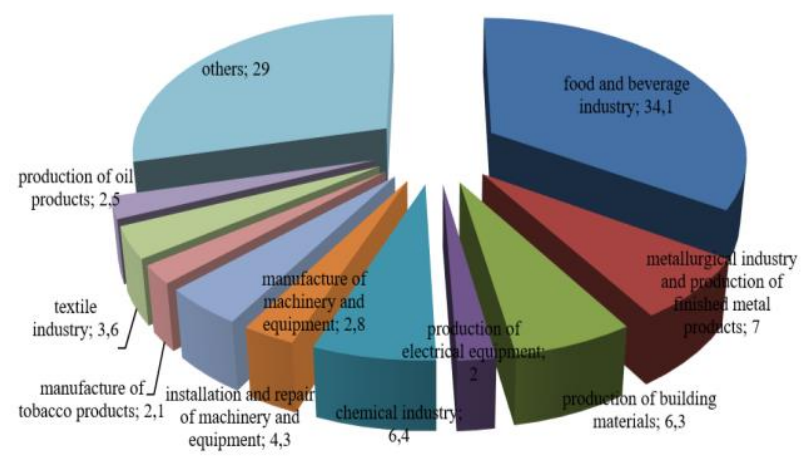

Figure 4 Structure of output of Azerbaijan's non-oil sector in $2019, \%$ (prepared based on materials of SSCRA. Retrieved from: https://www.stat.gov.az/).

Figure 4 shows the production output structure of the non-oil sector of Azerbaijan in 2019, which shows that food and beverages production is $34.1 \%$. This is due to the extensive development of agriculture and, in general, the agricultural sector in recent years. However, there are significant reserves and potential for developing the chemical and metallurgical industries, etc.

Figure 5 shows the dynamics of attracting foreign investment in specific sectors of the Azerbaijani economy in 2010-2019, where the volume of investment in the country, especially in the oil sector, has significantly decreased in recent years. As for investments in the economy's oil sector, we believe that the investment made is much less than the true potential. It also determines the implementation of more effective measures to ensure the attractiveness of the investment environment of the oil sector of the country's economy.

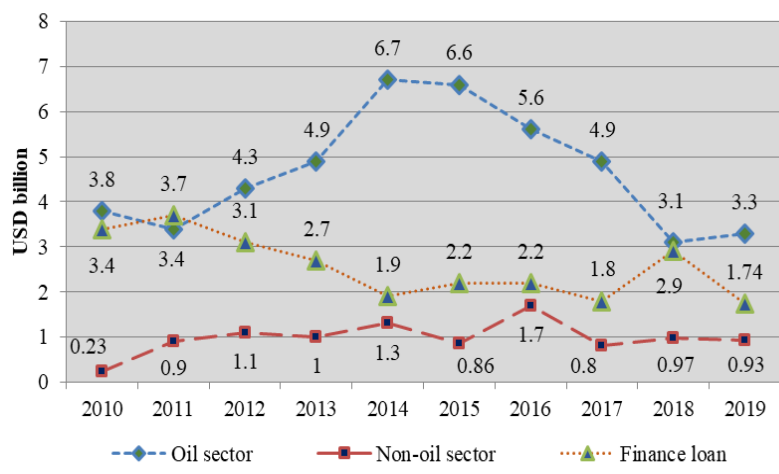

Figure 5 Dynamics of attracting foreign investment in specific sectors of the Azerbaijani economy in 20102019, USD billion (prepared based on materials of SSCRA. Retrieved from: https://www.stat.gov.az/).

It should be emphasised that the non-oil sectors of the country's economy are currently considered essential sources of expanding the potential for sustainability and growth of the national economy. According to the researchers F. Hasanova and F. Huseynova: "More investment and available credit resources are needed to accelerate the creation of new production capacities and the development of non-oil sectors of the economy" [13, p.603]. It is also vital to accelerate the formation and development of innovation-oriented and knowledgebased sectors in the country's economic structure. Moreover, there are severe prerequisites for this in Azerbaijan, since Azerbaijan has provided the production of two Azerbaijani communication satellites over the past decades, making it possible to intensify digitalisation creation competitive information and communication technology services. Researcher I.M. Makhmudova considers: "The country's regions have a large number of resources to diversify the structure of non-oil sectors, which will ensure the expansion of the country's economy soon" [14]. 


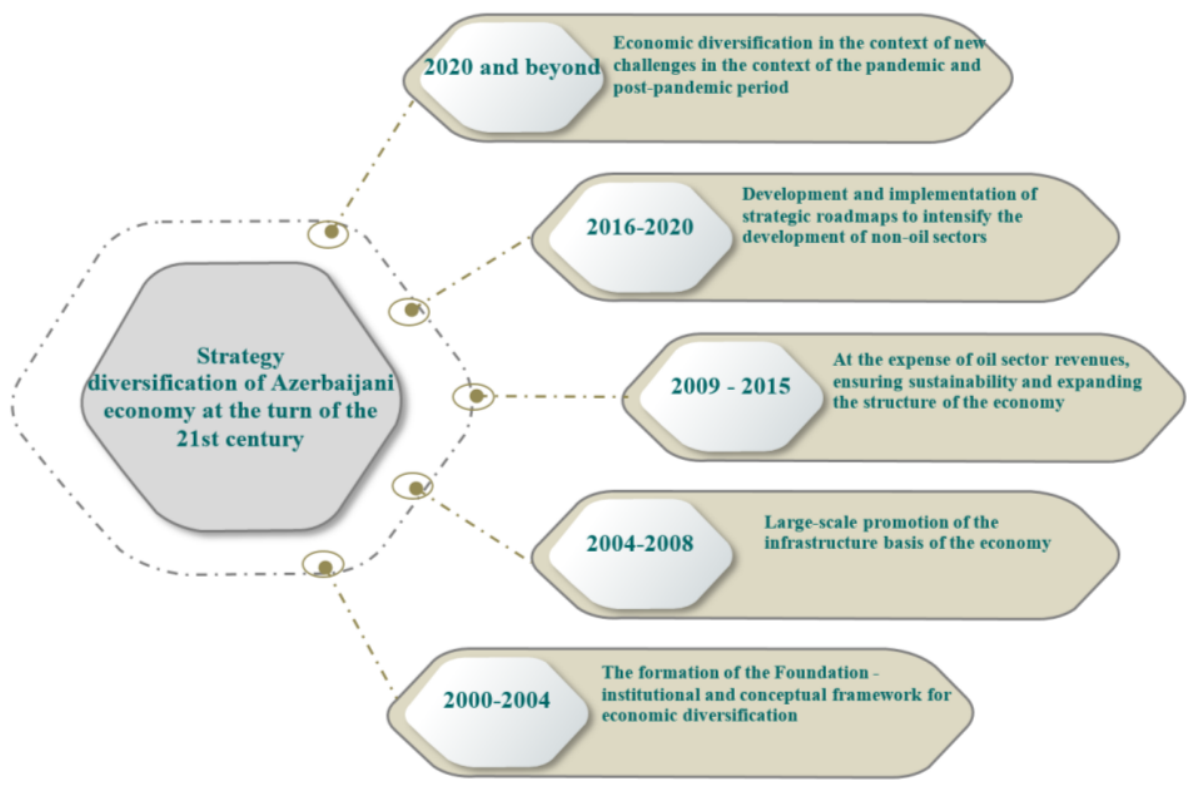

Figure 6 Strategy of diversification of the Azerbaijani economy at the turn of the 21 st century (developed by the author).

We believe that Azerbaijan should follow the strategy developed to diversify the Azerbaijani economy at the turn of the 21 st century, which is given in figure 6 .

\section{CONCLUSION}

We believe that Azerbaijan has serious prerequisites for solving the problem of diversification of the country's economy in the context of new challenges. This requires the implementation of a group of essential tasks:

- First of all, it is necessary to speed up the formation of the legislative framework for creating the country's innovation system, simplifying procedures and processes for the transfer of high technologies, and attracting direct investment in the non-oil sectors of the economy;

- productive use of traditional heavy industry sectors is required, which will increase the potential of non-oil exports;

- It is necessary to develop targeted programs to intensify the development of the knowledge economy and information and communication technologies, which could accelerate the depreciation of the country's economy's dependence on the oil factor;

- It is also necessary to bring the country's economy in line with the pandemic and post-pandemic period requirements and the proposed strategy of diversification of the Azerbaijani economy, thereby accelerating the diversification of the Azerbaijani economy soon, etc.

\section{ACKNOWLEDGMENTS}

The author thanks the analyst-economist Melikova Leyli Afras kyzy for useful advice on modern problems of economic diversification.

\section{REFERENCES}

[1] Strategic Roadmap for the National Economy Perspective of the Republic of Azerbaijan, Approved by the Decree of the President of the Republic of Azerbaijan dated December 6, 2016.

[2] Sh.T. Aliyev, The strategic importance of Sumgayit in the socio-economic development of Azerbaijan, Sumgait, "Azeri" publishing house, 2019, 368 p.

[3] A.S. Shakaraliyev, Z.A. Shakaraliyeva, Socioeconomic problems of the non-oil sector in current condition, 37th International Scientific Conference On Economic And Social Development Socioeconomic Problems Of Sustainable Development, 2019, pp. 651-656.

[4] T.N. Aliyev, Innovative industrial development of Azerbaijan: oil refining, chemistry and petrochemicals, Moscow-Berlin, "Palmarium." 2016, 232 p.

[5] O. Abdurazzakov, Stimulating Innovative Entrepreneurship: How to Apply US Experience for Azerbaijan, Proceedings Of The 11th European Conference On Innovation And Entrepreneurship, 2016, pp. 887-896, Jyvaskyla, Finland.

[6] G. Manafov, Conceptual basis of entrepreneurship development in the non-oil sector, 37th International 
Scientific Conference On Economic And Social Development - Socioeconomic Problems Of Sustainable Development, 2019, pp. 532-538, Baku, Azerbaijan.

[7] O. Brendan, H. Terence, H. David, L. Patrick, Searching for the Inclusive Growth Tax Grail: The Distributional Impact of Growth Enhancing Tax Reform in Ireland, The Economic and Social Review Vol. 47 Iss. 1 (2016) 155-184.

[8] T. Gerard, F. Darragh, Mc. Stephen, A Needs and Resources Assessment of Fiscal Equalisation in the Irish Local Government System, The Economic and Social Review Vol. 46 Iss. 3 (2015) 459-484.

[9] D. Acemoglu, J.A. Robinson, Economics versus Politics: Pitfalls of policy advice, Journal of Economic Perspectives Vol. 27 Iss. 2 (2013) 173192. DOI: https://doi.org/10.1257/jep.27.2.173

[10] N.G. Gurbanov, The Neseccarity To Diversify Industry In Azerbaijan, Financial and credit activityproblems of theory and practice 1(20) (2016) 46-50

[11] U. Aliyev, G. Guliyeva, Prospects of ensuring the sustainable development in Azerbaijan, 37th International Scientific Conference On Economic And Social Development - Socioeconomic Problems Of Sustainable Development, 2019, pp. 1604-1610, Baku, Azerbaijan.

[12] A.J. Muradov, Y.H. Hasanli, N.O. Hajiyev, The assessment of the impact of competitiveness on economic development, International Scientific Conference on Economic and Social Development, 2019, pp. 1171-1178, Baku, Azerbaijan.

[13] F. Hasanov, F. Huseynov. Bank credits and non-oil economic growth: Evidence from Azerbaijan, International Review Of Economics \& Finance 27 (2013) 597-610. DOI: https://doi.org/10.1016/j.iref.2013.02.005

[14] I.M. Mahmudova, Structural analysis of non-oil sector fields in the regions of the Republic of Azerbaijan, 37th International Scientific Conference On Economic And Social Development Socioeconomic Problems Of Sustainable Development, 2019, pp. 435-443, Baku, Azerbaijan. 